\title{
Analisa Keruntuhan Bendungan Batujai dan Pengga dengan Aplikasi HEC-RAS 5.0.7
}

\author{
Diah Fitri Maulida $^{1 *}$, Pitojo Tri Juwono ${ }^{2}$, Runi Asmaranto ${ }^{3}$ \\ ${ }^{1}$ Jurusan Teknik Pengairan, Fakultas Teknik, Universitas Brawijaya \\ Jalan MT Haryono No.167, Malang, 65145, INDONESIA \\ *Korespondensi Email: diahfitri13@ gmail.com
}

\begin{abstract}
Batujai and Pengga Dam are cascade dams with homogeneous types, are authorized in 1982 and 1994. These dams are located at the same mainstream that ends at Alas Strait. Batujai and Pengga Dam break may occur due to overtopping and piping. According to HEC-RAS 5.0.7 simulation suggested that the collapsed of each or both dams has the biggest impact when conditioned with design flood of QPMF are due to overtopping, when the peak of discharge are at $2036.151 \mathrm{~m}^{3} / \mathrm{second}$ and $3204,089 \mathrm{~m} 3 / \mathrm{second}$, which caused $34.127 \mathrm{~km}^{2}$ and $107,025 \mathrm{~km}^{2}$ area to be flooded, with maximum inundation of 19.656 meters and 19.837 meters. According to InaSAFE, if the collapse of these dams were merged, reported that there are 34 villages and 29,100 people are exposed to the risk, classified with high disaster risk. The cost that has to be paid by the dam's owner due to the collapse is estimated to be Rp 201,584,808.36/Ha or Rp. 2,845,409,886,907 in total.
\end{abstract}

Keywords: Batujai and Pengga Dam, Dambreak, InaSAFE, Overtopping, Piping,

\begin{abstract}
Abstrak: Bendungan Batujai dan Pengga merupakan bendungan bertingkat dengan jenis bendungan urugan yang diresmikan pada tahun 1982 dan 1994. Kedua bendungan ini berada pada satu sungai utama yang berakhir di Selat Alas. Keruntuhan Bendungan Batujai dan Pengga dapat disebabkan oleh overtopping maupun piping. Hasil simulasi dengan HEC-RAS 5.0.7 menunjukkan overtopping adalah penyebab utama keruntuhan yang memberikan dampak terbesar dengan banjir desain QPMF dimana puncak banjir berada pada Qinflow 2036,151 m³/detik dan 3204,089 m³/detik dan luas genangan $34,127 \mathrm{~km}^{2}$ dan $107,025 \mathrm{~km}^{2}$ dengan ketinggian banjir masing masing 19,656 meter dan 19,837 meter. Dengan bantuan aplikasi InaSAFE, jika dipadukan keruntuhan kedua bendungan ini mengakibatkan 34 Desa terdampak banjir dan 29.100 jiwa, dengan klasifikasi bahaya tingkat tinggi. Kerugian yang harus ditanggung oleh Pengelola Bendungan ditaksir sekitar Rp 201.584.808,36/Ha atau dengan total Rp. 2.845.409.886.907.
\end{abstract}

Kata kunci: Bendungan Batujai dan Pengga, InaSAFE, Keruntuhan Bendungan, Overtopping, Piping

\section{Pendahuluan}

Permasalahan ketidakseimbangan antara peningkatan kebutuhan air dan ketersediannya yang semakin menurun menyebabkan penggunaan air perlu dikekola dengan memperhatikan aspek sosial, lingkungan hidup dan ekonomi di berbagai sektor. Salah satu cara untuk mengelola air adalah dengan 
membentuk wadah buatan berupa bendungan yang nantinya membentuk waduk yang akan menampung air [1].

Namun dengan seiring berjalanannya waktu, pembangunan bendungan menyimpan berbagai macam resiko salah satunya yaitu akan terjadinya keruntuhan bendungan. Dalam Permen PU No.27 Pasal 1 Tahun 2015 disebutkan bahwa kegagalan bendungan adalah keruntuhan sebagian atau seluruh bendungan atau bagunan pelengkapnya yang akan menyebabkan tidak berfungsinya bendungan [2]. Keruntuhan ini menyebabkan banjir yang memberikan banyak korban jiwa, hilang atau rusaknya harta benda, kerusakan lingkungan, dan dapat memberikan dampak psikologis yang berkepanjangan pada korban bencana.

Maka dari itu, selain harus dilakukannya inspeksi setiap 5 tahun sekali untuk mencegah dan meminimalisir adanya kerusakan di tubuh bendungan, bangunan pelengkap, serta instrument yang ada di bendungan, setiap bendungan harus dilengkapi dengan Dokumen Rencana Tindak Darurat (RTD) untuk mengantisipasi penyelamatan jiwa dan harta benda apabila terjadi keruntuhan. Salah satu bentuk dari Rencana Tindak Darurat adalah melakukan analisis keruntuhan bendungan agar dapat diketahui resiko bahaya bendungan pada daerah terdampak sesuai dengan klasifikasi yang telah diberikan.

\section{Bahan dan Metode}

\subsection{Bahan}

\section{a. Data Hujan}

Data hujan yang digunkan dalam penelitian ini memiliki rentang waktu selama 30 tahun dari tahun 1999 - 2019, dimana nantinya data hujan ini digunakan untuk melakukan analisis hidrologi dari uji kualitas data sampai dengan flood routing.

b. Data Teknis dan Peta Isohayet Pulau Lombok tahun 2019/2020 [3]

Data teknis yang digunakan pada penelitian ini yaitu berupa data teknis tinggi bendungan, lengkung kapasitas waduk, dan dimensi bendungan. Sementara untuk Peta Isohayet Pulau Lombok yang digunakan pada penelitian ini yaitu tahun 2019/2020. Nantinya peta ini digunakan untuk membandingkan hasil PMP hitung dengan PMP Peta. Apabila nilai PMP Hitung > PMP Peta, maka yang digunakan adalah PMP Hitung pada perhitungan selanjutnya, begitupula dengan sebaliknya.

\section{c. Peta DEM dan Peta RBI}

Peta DEM atau Digital Elevation Model digunakan pada penelitian ini untuk menggambarkan kondisi bagian hilir bendungan pada software HEC-RAS, sementara peta RBI dengan skala 1:25.000 nantinya digunakan untuk overlay agar mengetahui daerah mana saja yang terdampak banjir oleh keruntuhan bendungan.

\section{d. Data Jumlah Penduduk}

Sesudah melakukan overlay terhadap peta banjir untuk mendapatkan daerah terdampak, selanjutnya adalah menggunakan data jumlah penduduk agar mengetahui berapa jumlah jiwa yang terdampak. Tahap ini digunakan pada aplikasi InaSAFE.

\section{e. Data OSM}

Data OSM ini nantinya akan digunakan pada aplikasi InaSAFE untuk menentukan unit daerah terdampak. Biasanya yang digunakan adalah data dalam bentuk .shp. Dalam penelitian ini penulis menggunakan 4 basis data, yaitu data bangunan, tata guna lahan, jalan, dan penduduk. 


\subsection{Metode}

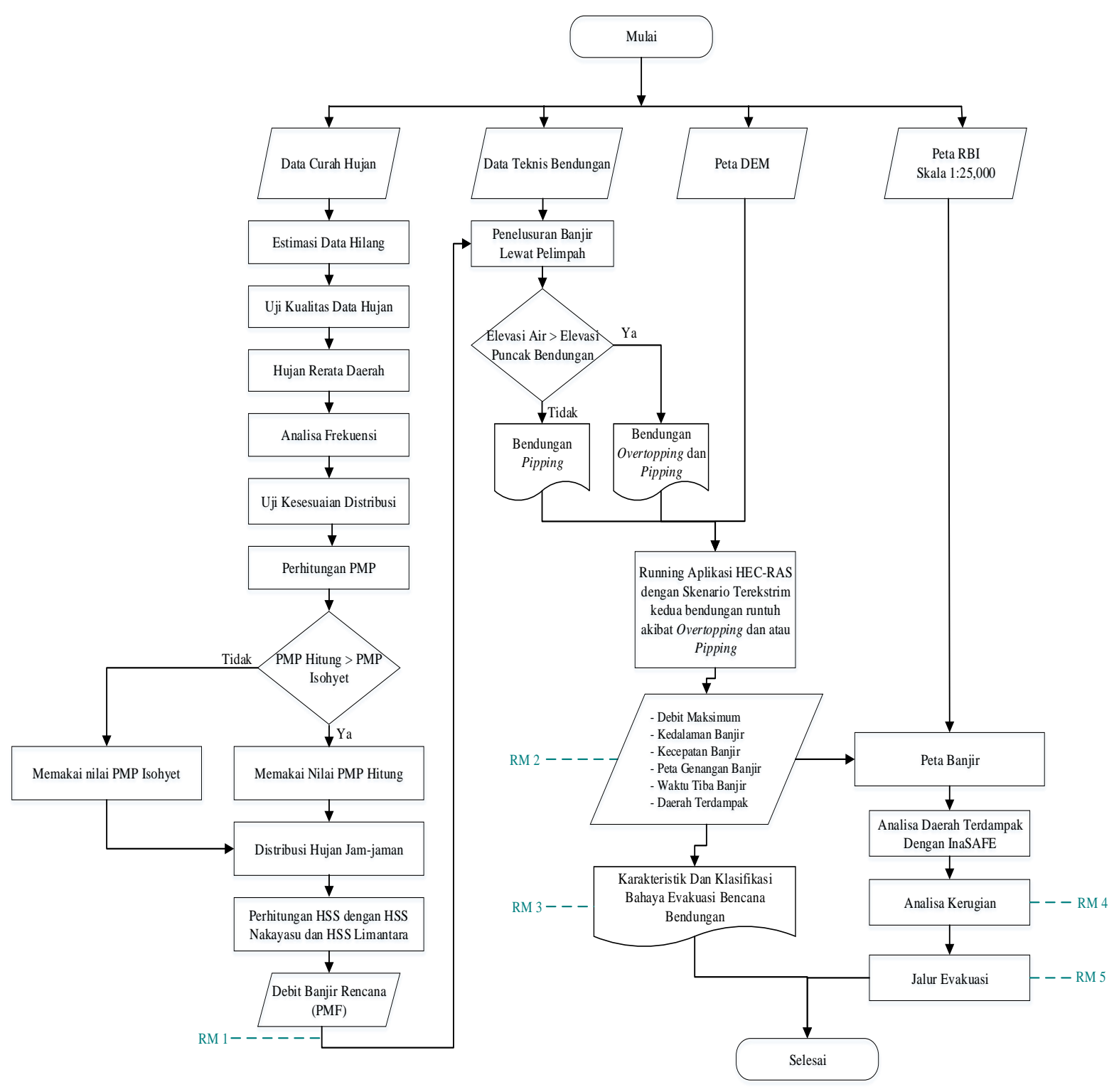

Gambar 1: Diagram Pengerjaan

\subsection{Persamaan}

\subsubsection{Analisa Frekuensi}

Tujuan dari analisa frekunsi sangat erat hubungannya dengan besarnya kejadian ekstrim terhadap frekuensi kejadian dengan menggunakan distribusi peluang (probabilitas). Dalam distribusi peluang, biasanya akan diperkirakan kemungkinan terjadinya suatu debit dengan besaran tertentu atau akan diperkirakan berapa besar debit dengan suatu kala ulang tertentu.

\subsubsection{Distribusi Normal}

Distribusi Normal atau kurva normal biasa disebut distribusi Gauss. Fungsi densitas peluang distribusi ini terdapat dari variable kontinyu X [4]

$$
\mathrm{X}=\text { Xrerata }+ \text { K.Sd }
$$

Pers. 1 


\subsubsection{Distribusi Log Normal}

Distribusi Log Normal dalam bentuk sederhana adalah fungsi kepadatan dari sebuah perubahan acak yang logaritmanya mengikuti hukum distribusi normal. Selain mempunyai fungsi kepekatan peluang, distribusi Log Normal juga memiliki fungsi distribusi komulatif. [4]

$$
\log X t=\overline{\log x}+K_{X} S_{\log x}
$$

Pers. 2

\subsubsection{Distribusi Log Pearson Tipe III}

Untuk menghitung banjir perencanaan dalam praktek, The Hydrology of Water Resources Council, USA menganjurkan untuk mentransformasikan data keharga logaritmanya, kemudian menghitung parameter statistiknya. [5]

$$
\log \mathrm{Xt}=\log \mathrm{X}+\mathrm{K} . \mathrm{S}
$$

Pers. 3

\subsubsection{Distribusi Gumbel}

Metode Gumbel biasanya digunakan pada analisis data maksimum, yaitu seperti analisis frekuensi banjir. Sementara persoalan yang biasanya dibicarakan berhubungan dengan nilai-nilai ekstrim yang datang dari persoalan banjir [5]. Tujuan dari teori statistik nilai ekstrim adalah untuk menganalisa hasil dari pengamatan nilai ektrim tersebut untuk memperkirakan nilai ekstrim berikutnya.

$$
\begin{array}{ll}
\mathrm{Yt}=-\operatorname{In}\left[-\ln \left(\frac{\operatorname{Tr}(X)-1}{\operatorname{Tr}(X)}\right)\right] & \text { Pers. } 4 \\
\operatorname{Tr}=\frac{1}{1-e^{-e^{-Y t}}} & \text { Pers. } 5 \\
\mathrm{~K}=\frac{Y t-Y n}{S n} & \text { Pers. } 6 \\
\mathrm{X}=\bar{X}+S d . K & \text { Pers. 7 }
\end{array}
$$

\subsubsection{Uji Kesesuaian Distribusi}

Untuk menentukan apakah pemilihan distribusi yang diguakan dalam perhitungan curah hujan rancangan diterima atau ditolak perlu dilakukan sebuah pengujian hipotesis berdasarkan pada derajat kepercayaan (level of significance) dan derajat kebebasan (degress of freedom), pengujian hipotesis tersebut menentukan suatu hipotesis diterima atau ditolak, yaitu dengan menggunakan Uji Smirnov Kolmogorov dan Chi Square [6].

\subsubsection{Debit Banjir Rancangan}

Hidrograf satuan digunakan dalam analisis banjir rancangan [7]. Hidrograf satuan sintetis yang telah dikembangkan oleh beberapa pakar antara lain yaitu HSS Nakayasu, HSS Snyder, HSS Gama I, HSS Limantara, dan banyak lainnya [8]. Debit Banjir Rencana pada penelitian ini dihitung dengan Hidrograf Satuan Sintetis. Perhitungan Hidrograf Satuan Sintetis (HSS) dilakukan pada Bendungan Batujai dan Bendungan Pengga dengan Metode Nakayasu.

Rumus Hidrograf Satuan Sintetis Nakayasu:

$$
\begin{array}{lll}
\operatorname{tg} & =0.21 \mathrm{~L}^{0.7}(\text { untuk } \mathrm{L}<15 \mathrm{~km}) & \text { Pers. } 8 \\
\operatorname{tg} & =0.4+0.058 \mathrm{~L}(\text { untuk } \mathrm{L}>15 \mathrm{~km}) & \text { Pers. } 9 \\
\operatorname{tr} & =0.5 \text { sampai } 1 \mathrm{tg} & \text { Pers. } 10 \\
\mathrm{Tp} & =\operatorname{tg}+0.8 \mathrm{tr} & \text { Pers. } 11 \\
\mathrm{~T}_{0.3} & =\alpha \operatorname{tg} & \text { Pers. } 12 \\
\mathrm{Qp} & =\frac{1}{3.6}\left[\frac{\text { CA } \mathrm{xo}}{0.3 \mathrm{Tp}+\mathrm{T} 0.3}\right] & \text { Pers. } 13
\end{array}
$$

Rumus Hidrograf Satuan Sintetis Limantara:

$$
\mathrm{Qp}=0.042 \cdot \mathrm{A}^{0.451} \cdot \mathrm{L}^{0.497} \cdot \mathrm{Lc}^{0.356} \cdot \mathrm{S}^{-0.131} \cdot \mathrm{n}^{0.16} \quad \text { Pers. } 14
$$




$$
\mathrm{n}=0.035(1+\mathrm{Af} / \mathrm{A})
$$

\subsubsection{Keruntuhan Bendungan}

Pembangunan bendungan menyimpan segudang resiko kegagalan, salah satunya yaitu keruntuhan bendungan yang bisa disebabkan oleh overtopping dan atau piping.
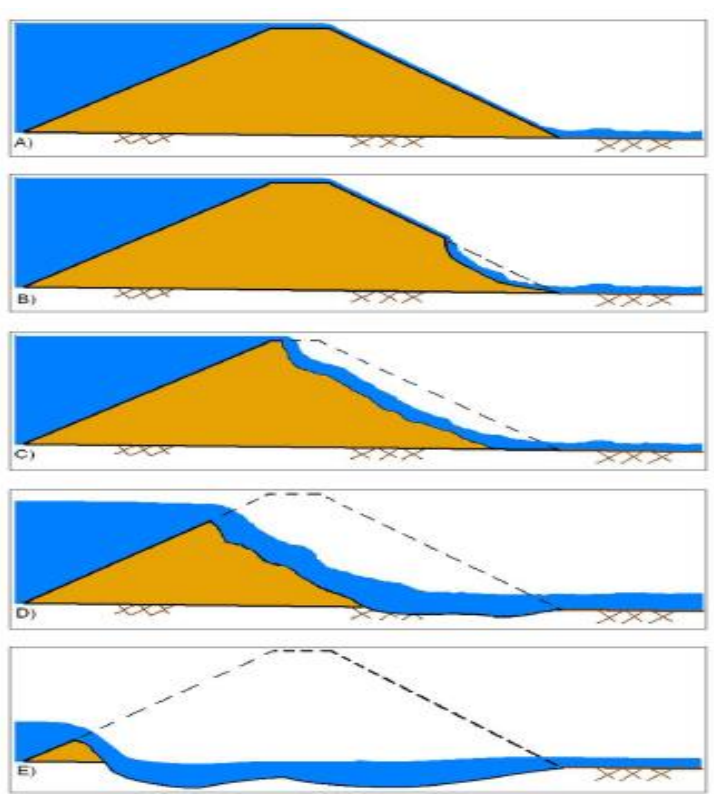

Gambar 2: Proses Keruntuhan Bendungan akibat Overtopping
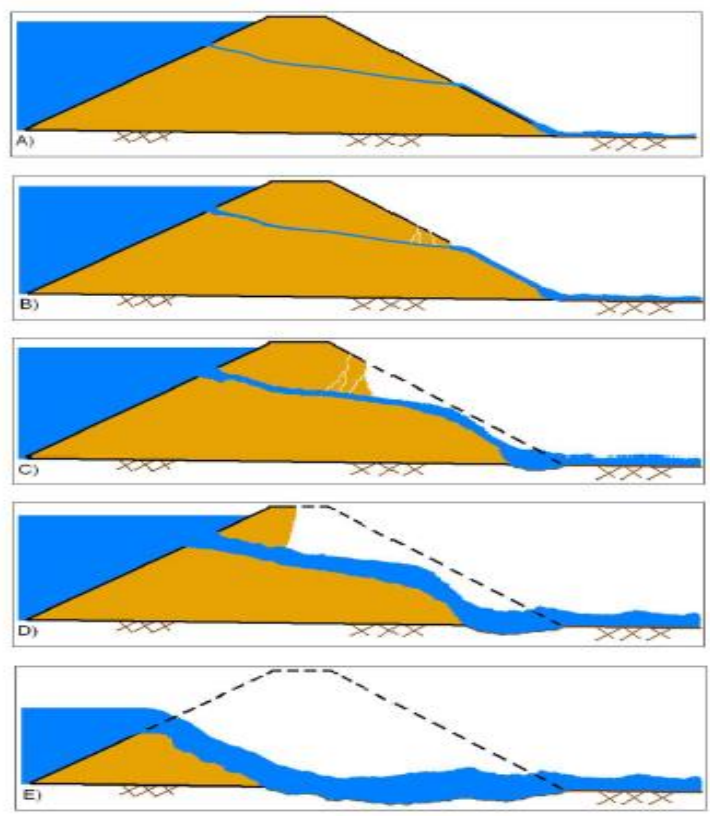

Gambar 3: Proses Keruntuhan Bendungan

akibat Piping

Pada keruntuhan bendungan dengan sekenario piping, air yang keluar melalui celah bendungan dimodelkan dengan persamaan tekanan aliran orifice. Persamaan ini juga membutuhkan koefisien debit dan menghitung seberapa efisien aliran bisa mengalir melalui pipa. Karena keruntuhan bendungan dengan sekenario piping tidak didesain secara hidrolika, maka diasumsikan bahwa rekahan tidak merata. Nilai yang direkomendasikan untuk koefisien tekanan untuk sekenario piping yaitu berkisar 0,5 sampai 0,6 [9]. Berikut adalah koefisien keruntuhan bendungan sesuai dengan jenis bendungannya.

Tabel 1: Koefisien Keruntuhan Bendungan

\begin{tabular}{lcc}
\hline \multicolumn{1}{c}{ Dam Types } & Overflow/Weif Coefficient & $\begin{array}{c}\text { Piping/Pressure Flow } \\
\text { Coefficients }\end{array}$ \\
\hline Earthen Clay or Clay Core & $2,6-3,3$ & $0,5-0,6$ \\
Earthen Sand and Gravel & $2,6-3,0$ & $0,5-0,6$ \\
Concrete Arch & $3,1-3,3$ & $0,5-0,6$ \\
Concrete Gravity & $2,6-3,0$ & $0,5-0,6$ \\
\hline
\end{tabular}

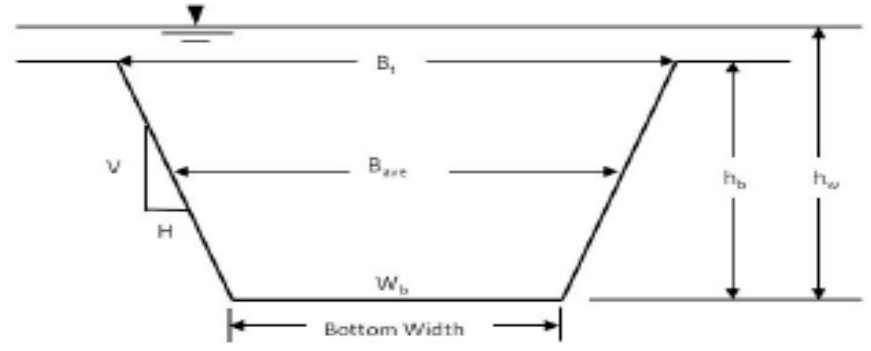

Gambar 4: Sketsa parameter keruntuhan bendungan 
Pada penelitian ini, penulis menggunakan persamaan yang ditemukan oleh Froehlich yang tercantum pada user guide di aplikasi HEC-RAS [9], yang sudah digunakan untuk beberapa perhitungan keamanan bendungan. Berdasakan penelitian terbarunya, Froehlich menyatakan bahwa sisi rata-rata lereng adalah $1,0 \mathrm{H}: 1,0 \mathrm{~V}$ untuk keruntuhan overtopping dan $0.7 \mathrm{H}: 1.0 \mathrm{~V}$ untuk keruntuhan piping [9]. Berikut adalah persamaan regresi untuk lebar rerata keruntuhan bendungan dan waktu runtuhnya:

$$
\begin{aligned}
& \mathrm{B}_{\mathrm{ave}}=0.27 \cdot \mathrm{K}_{\mathrm{o}} \cdot \mathrm{V}_{\mathrm{w}}^{0.32} \cdot \mathrm{h}_{\mathrm{b}}^{0.04} \\
& \mathrm{tf} \quad=63.2 \sqrt{\frac{V w}{g h b^{2}}}
\end{aligned}
$$

Pers. 17

dimana:

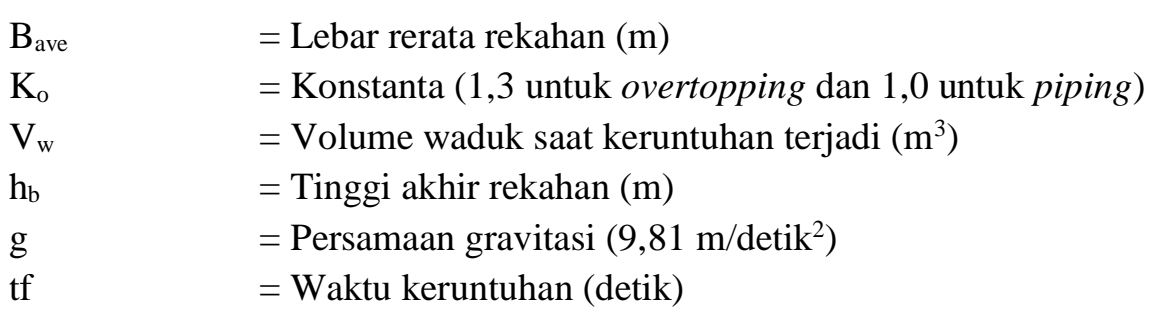

\section{Aplikasi HEC-RAS}

HEC-RAS (Hydraulic Engineering Center's River Analysis System) adalah aplikasi yang memungkinkan penggunanya untuk melakukan simulasi hidraulik aliran satu dimensi, perhitungan aliran sungai tidak seragam satu maupun dua dimensi, pemodelan pergerakan sedimen dalam aliran tidak seragam dan aliran tidak seragam penuh, analisis suhu air, dan pemodelan kualitas air secara umum. Dalam melakukan simulasi keruntuhan bendungan dengan HEC-RAS biasanya dilakukan beberapa tahap, yaitu:

\footnotetext{
- $\quad$ Memulai proyek baru

- $\quad$ Memasukkan data geometris sesuai dengan lokasi bendungan

- $\quad$ Memasukkan data aliran dan kondisi batas

- $\quad$ Melakukan perhitungan hidraulik

- $\quad$ Melihat dan mencetak hasil banjir akibat keruntuhan bendungan

$4 \quad$ Klasifikasi Tingkat Bahaya
}

Untuk mendapatkan klasifikasi tingkat bahaya dan karakteristik banjir, digunakan bantuan aplikasi InaSAFE 5.0.1 dengan analisa ancaman (hazard) berdasarkan Peraturan BNPB No.02 Tahun 2012. Dimana indeks yang digunakan merupakan indeks tinggi banjir yang telah disusun berdasaran data dan catatan sejarah kejadian yang pernah terjadi di suatu daerah [10]. Menurut Peraturan BNPB No.02 Tahun 2012 klasifikasi bahaya terdiri dari indeks ancaman dengan ketinggian banjir $<1$ meter merupakan ancaman rendah, 1 - 3 meter merupakan ancaman sedang, dan > 3 meter merupakan ancaman tinggi.

\section{Hasil dan Pembahasan}

\subsection{Analisa Hidrologi}

Dalam melakukan analisis hidrologi, penulis melakukan dua kali perhitungan sebab masingmasing bendungan memiliki DTA (Daerah Tangkapan Air) tersendiri dengan rentang data sepanjang yang sama, yaitu 30 tahun (1999-2020).

a. Hujan PMP (Probable Maximum Precipitation) yaitu ketebalan hujan maksimum dalam lama waktu tertentu yang mungkin terjadi pada suatu wilayah yang nantinya kemudian akan digunakan 
dalam melakukan perhitungan banjir PMF (Probable Maximum Flood) [6]. Berikut adalah perhitungan hujan PMP dengan Metode Hersfield:

Tabel 2: Perhitungan Hujan PMP Metode

Hersfield Batujai

\begin{tabular}{cccc}
\hline No. & Tahun & $\begin{array}{c}\text { Curah } \\
\text { Hujan } \\
(\mathrm{mm})\end{array}$ & $\begin{array}{c}\text { Curah } \\
\text { Hujan } \\
\text { Terurut } \\
(\mathrm{mm})\end{array}$ \\
\hline 1 & 1990 & 101,00 & 49,00 \\
2 & 1991 & 95,40 & 54,50 \\
3 & 1992 & 97,00 & 55,00 \\
4 & 1993 & 137,70 & 59,50 \\
5 & 1994 & 80,00 & 60,00 \\
6 & 1995 & 65,70 & 65,70 \\
7 & 1996 & 81,10 & 80,00 \\
8 & 1997 & 100,90 & 81,00 \\
9 & 1998 & 49,00 & 81,10 \\
10 & 1999 & 60,00 & 83,50 \\
11 & 2000 & 83,50 & 86,30 \\
12 & 2001 & 59,50 & 89,20 \\
13 & 2002 & 100,50 & 90,00 \\
14 & 2003 & 108,20 & 90,01 \\
15 & 2004 & 94,00 & 93,07 \\
16 & 2005 & 90,01 & 94,00 \\
17 & 2006 & 55,00 & 94,50 \\
18 & 2007 & 94,50 & 95,40 \\
19 & 2008 & 54,50 & 97,00 \\
20 & 2009 & 141,90 & 100,50 \\
21 & 2010 & 81,00 & 100,90 \\
22 & 2011 & 90,00 & 101,00 \\
23 & 2012 & 110,00 & 108,20 \\
24 & 2013 & 113,70 & 110,00 \\
25 & 2014 & 133,00 & 113,70 \\
26 & 2015 & 134,70 & 118,40 \\
27 & 2016 & 89,20 & 133,00 \\
28 & 2017 & 118,40 & 134,70 \\
29 & 2018 & 86,30 & 137,70 \\
30 & 2019 & 93,07 & 141,90 \\
\hline Total X & & & 2798,781 \\
Xrerata & & & 93,293 \\
Jumlah Data (n) & & 30 \\
Standar Deviasi (Sd) & & 24,891 \\
Xrerata - m & & 91,617 \\
Standar Deviasi - m & & 23,546 \\
\hline & & & \\
\hline & &
\end{tabular}

Tabel 3: Perhitungan Hujan PMP Metode Hersfield Pengga

\begin{tabular}{cccc}
\hline No. & Tahun & $\begin{array}{c}\text { Curah } \\
\text { Hujan } \\
(\mathrm{mm})\end{array}$ & $\begin{array}{c}\text { Curah } \\
\text { Hujan } \\
\text { Terurut } \\
(\mathrm{mm})\end{array}$ \\
\hline 1 & 1990 & 78,152 & 23,96 \\
2 & 1991 & 44,582 & 25,18 \\
3 & 1992 & 46,744 & 27,86 \\
4 & 1993 & 77,999 & 29,52 \\
5 & 1994 & 25,183 & 29,94 \\
6 & 1995 & 46,755 & 30,64 \\
7 & 1996 & 23,957 & 33,09 \\
8 & 1997 & 50,142 & 39,00 \\
9 & 1998 & 73,142 & 40,62 \\
10 & 1999 & 74,657 & 43,12 \\
11 & 2000 & 72,428 & 44,57 \\
12 & 2001 & 48,248 & 44,58 \\
13 & 2002 & 56,271 & 45,69 \\
14 & 2003 & 44,571 & 46,74 \\
15 & 2004 & 46,800 & 46,76 \\
16 & 2005 & 27,863 & 46,80 \\
17 & 2006 & 29,944 & 48,25 \\
18 & 2007 & 30,643 & 50,14 \\
19 & 2008 & 33,094 & 52,20 \\
20 & 2009 & 45,694 & 55,45 \\
21 & 2010 & 39,000 & 56,27 \\
22 & 2011 & 29,517 & 56,83 \\
23 & 2012 & 52,204 & 61,29 \\
24 & 2013 & 40,615 & 62,96 \\
25 & 2014 & 43,123 & 72,43 \\
26 & 2015 & 56,828 & 73,14 \\
27 & 2016 & 78,557 & 74,66 \\
28 & 2017 & 61,285 & 78,00 \\
29 & 2018 & 62,957 & 78,15 \\
30 & 2019 & 55,455 & 78,56 \\
\hline Total X & & & 1496,410 \\
Xrerata & & & 49,880 \\
Jumlah Data (n) & & 30 \\
Standar Deviasi (Sd) & & 16,701 \\
Xrerata - m & & 48,891 \\
Standar Deviasi - m & & 16,078 \\
\hline & & & \\
\hline
\end{tabular}

Contoh Perhitungan Hujan PMP Batujai

$$
\begin{aligned}
\text { Xn terkoreksi }(\mathrm{Xp}) & =\mathrm{Xn} \cdot f 1 \cdot f 2 \\
& =93,29 \times 1,029 \times 1,01 \\
& =96,96 \mathrm{~mm} \\
\text { Sn terkoreksi }(\mathrm{Sp}) & =\mathrm{Sn} \cdot f 3 \cdot f 4
\end{aligned}
$$




$$
\begin{aligned}
& =24,89 \times 1,14 \times 1,04 \\
& =29,51 \\
& =\mathrm{Xp}+\mathrm{Km} \cdot \mathrm{Sp} \\
& =96,96+15,7 \times 29,51 \\
& =560,285 \mathrm{~mm} \\
& =560,285 \times 1,13 \text { (Faktor pengali SNI) } \\
\mathrm{PMP}_{\text {hitung }} & =633,125 \mathrm{~mm}
\end{aligned}
$$

Berdasarkan nilai Peta PMP Isohyet Pulau Lombok, PMP yang terjadi di Bendungan Batujai yaitu sebesar 542,70 mm, namun hasil $\mathrm{PMP}_{\text {hitung }}$ lebih besar sebesar $633,125 \mathrm{~mm}$, maka dari itu untuk perhitungan selanjutnya digunakan nilai PMP terbesar yaitu $\mathrm{PMP}_{\text {hitung, }}$, sementara untuk Bendungan Pengga menggunaan $\mathrm{PMP}_{\text {peta. }}$

HSS Limantara juga sesuai dengan wilayah penelitian, khususnya HSS Limantara yang dianggap mewakili lokasi di Indonesia, yaitu Pulau Jawa, Bali, Lombok, dan Kalimantan [8].

Tabel 4: Rekapitulasi Nilai Hidrograf Satuan Sintetis Batujai

\begin{tabular}{lccccccc}
\hline \multirow{2}{*}{ Metode HSS } & \multicolumn{7}{c}{ Debit Banjir Rancangan $\left(\mathrm{m}^{3} / \mathrm{dt}\right)$} \\
& 5 tahun & 10 tahun & 25 tahun & 50 tahun & 100 tahun & 1000 tahun & PMF \\
\hline Nakayasu & 430,598 & 462,004 & 495,972 & 515,660 & 534,592 & 581,316 & 2036,151 \\
Limantara & 119,622 & 128,474 & 137,972 & 143,625 & 148,984 & 162,320 & 569,537 \\
\hline
\end{tabular}

Tabel 5: Rekapitulasi Nilai Hidrograf Satuan Sintetis Pengga

\begin{tabular}{lccccccc}
\hline \multirow{2}{*}{ Metode HSS } & \multicolumn{7}{c}{ Debit Banjir Rancangan $\left(\mathrm{m}^{3} / \mathrm{dt}\right)$} \\
& 5 tahun & 10 tahun & 25 tahun & 50 tahun & 100 tahun & 1000 tahun & PMF \\
\hline Nakayasu & 419,369 & 481,516 & 554,866 & 615,415 & 673,267 & 856,979 & 3204,089 \\
Limantara & 277,877 & 320,274 & 369,751 & 411,775 & 451,407 & 578,272 & 2186,260 \\
\hline
\end{tabular}

Berdasarkan hasil perhitungan yang telah dilakukan, kedua bendungan menggunakan HSS Metode Nakayasu sebab memberikan hasil debit yang lebih besar yaitu sebesar QPMF Batujai $=2036,151$ $\mathrm{m}^{3} /$ detik dan QPMF Pengga $=3024,089 \mathrm{~m}^{3} /$ detik dibandingkan HSS Metode Limantara. Selisih kedua debit sangatlah jauh, untuk itu perlu dilakukan pengecekan dengan data nilai debit sungai tercatat (AWLR) pada AWLR Karang Anyar sebesar QPMF $=2812,36 \mathrm{~m}^{3} /$ detik. Hasilnya perhitungan HSS Metode Nakayasu lebih mendekati data yang tercatat, oleh sebab itu untuk perhitungan selanjutnya akan menggunakan perhitungan hasil HSS Nakayasu.

b. Penelusuran Banjir diatas Pelimpah Bendungan

Perhitungan penelusuran banjir atau flood routing melalui pelimpah dilakukan untuk mengetahui tinggi muka air yang ada diatas mercu pelimpah saat suatu debit dengan kala ulang tertentu melewati pelimpah. Pada studi analisa keruntuhan bendungan, hasil analisa penelusuran banjir melewati pelimpah digunakan untuk mentukan apakah bendungan mengalami overtopping atau tidak.

Dalam melakukan penelusuran banjir pada pelimpah Bendungan Pengga, terdapat beberapa perbedaan, yaitu Qinflow yang masuk ke Waduk Pengga berasal dari Qoutflow hasil routing dari Bendungan Batujai ditambah dengan Qinflow yang berasal dari Bendungan Pengga. 


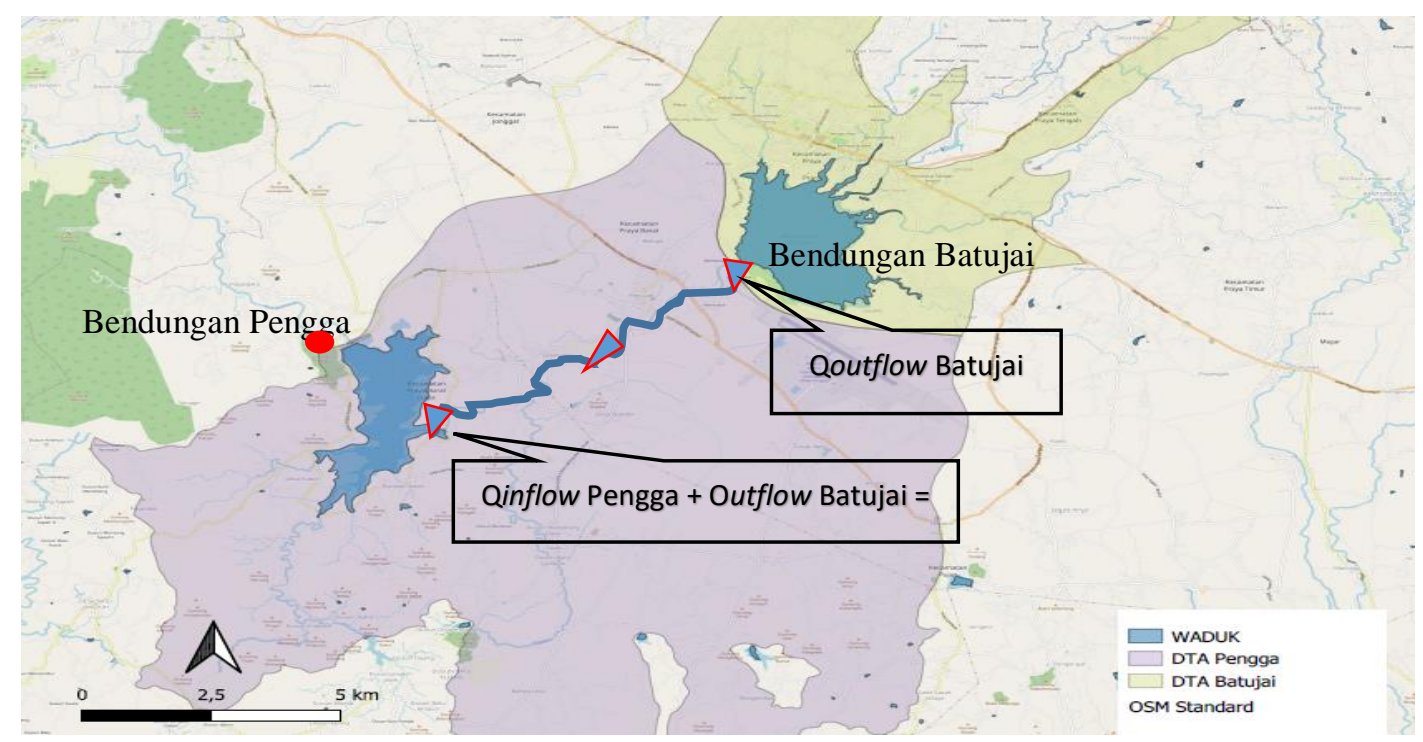

Gambar 5: Peta Skema Inflow dan Outflow yang diterima Waduk Pengga

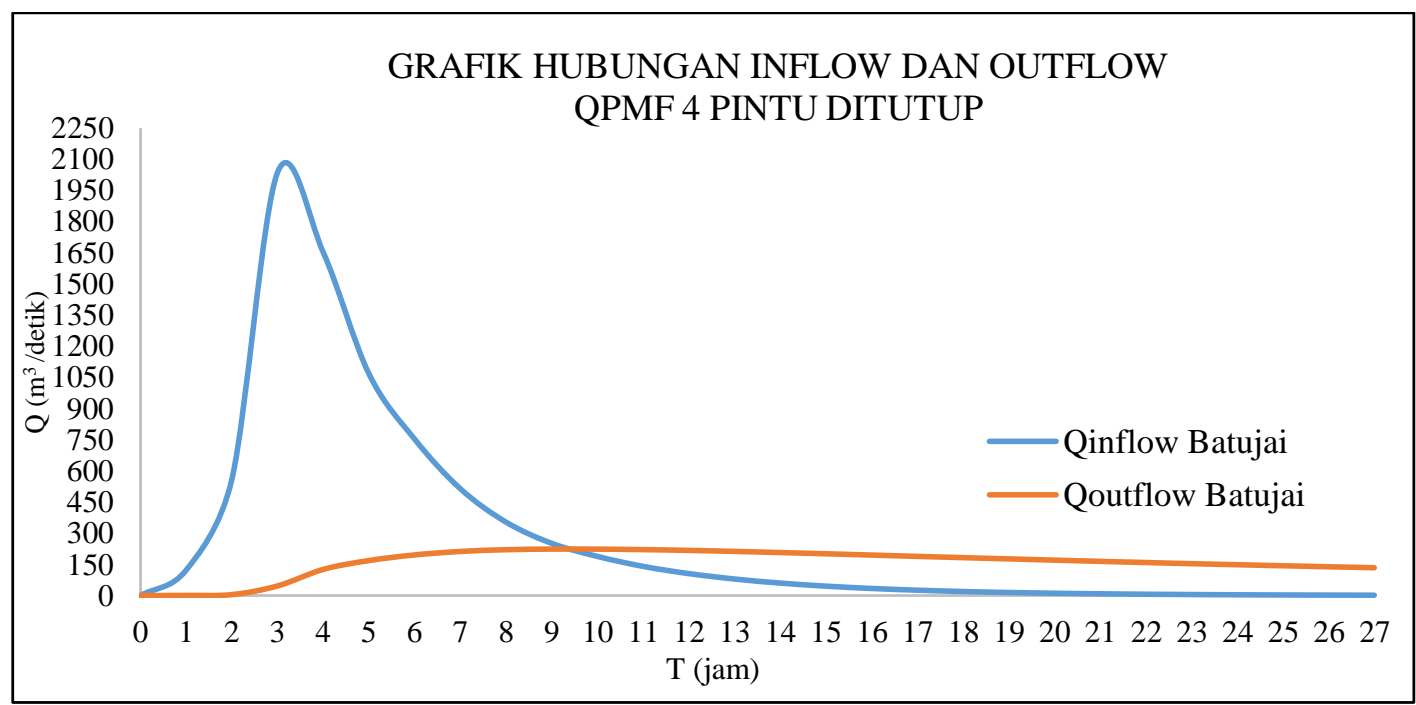

Gambar 6: Grafik Hubungan Inflow dan Outflow pada Pelimpah Bendungan Batujai dengan QPMF

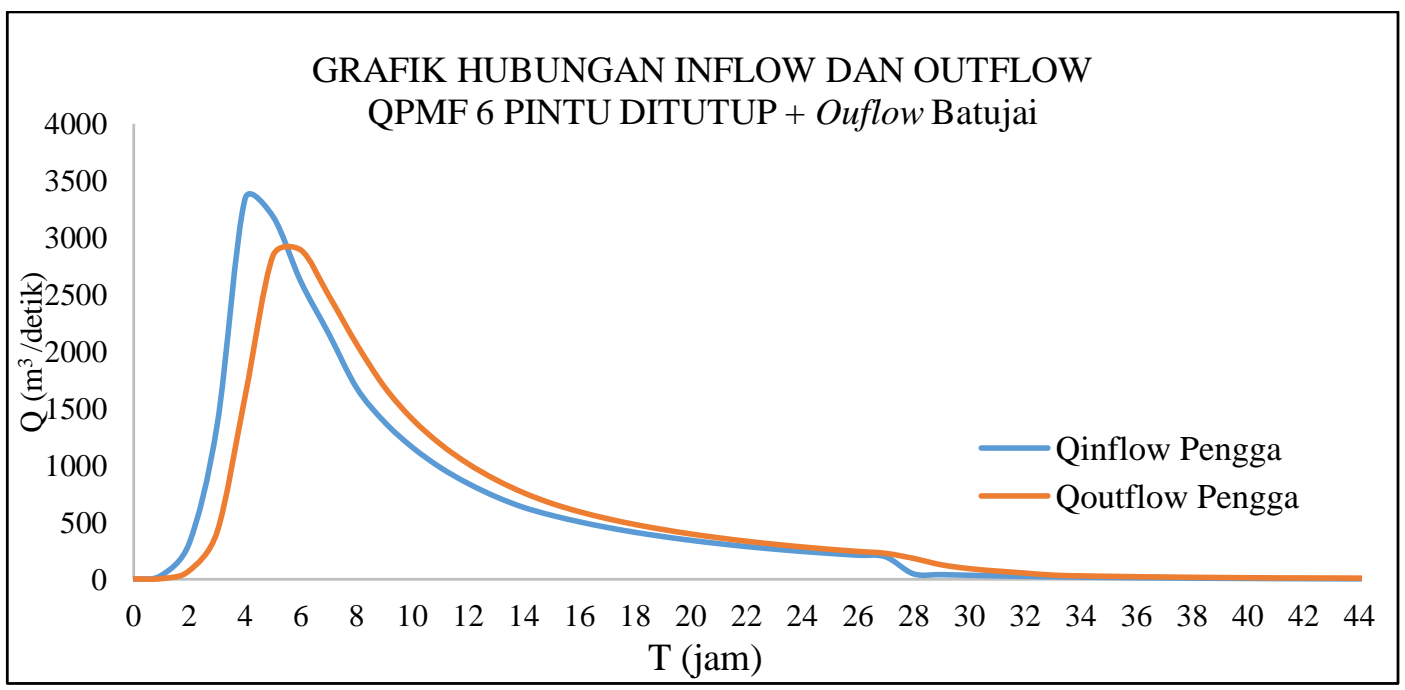

Gambar 7: Grafik Hubungan Inflow dan Outflow pada Pelimpah Bendungan Pengga dengan QPMF 
Dari Gambar 6 dan Gambar 7, dapat diketahui bahwa apabila Bendungan Batujai dengan 4 (empat) pintu, dan Bendungan Pengga dengan 6 (enam) pintu jika disimulasikan menerima banji sebesar QPMF dengan sekenario semua pintu tidak dapat dibuka maka akan menghasilkan overtopping dengan ketinggian air 5,876 meter diatas pelimpah untuk Bendungan Batujai dan 10,535 meter untuk Bendungan Pengga.

\subsection{Analisa Keruntuhan Bendungan dengan HEC-RAS 5.0.7}

a. Parameter Keruntuhan

Keruntuhan Bendungan Batujai disimulasikan menggunakan bantuan aplikasi HEC-RAS versi 5.0.7 dengan pemodelan 2D. Selain HEC-RAS dengan 7 (tujuh) macam sekenario. Parameter keruntuhan bendungan dihitung dengan rumus Froehlich [9].

Contoh perhitungan untuk sekenario overtopping untuk Bendungan Batujai:

$\mathrm{B}_{\text {ave }}$

$$
\begin{aligned}
& =0,27 \mathrm{~K}_{\mathrm{o}} \mathrm{V}_{\mathrm{w}}^{0.32} \mathrm{~h}_{\mathrm{b}}^{0.04} \\
& =0,271,3 \cdot 25574800^{0.32} 15^{0.04} \\
& =91,802 \\
& =63,2 \sqrt{\frac{\mathrm{Vw}}{\mathrm{ghb}^{2}}} \\
& =63,2 \sqrt{\frac{25574800}{9.81(15)^{2}}} \\
& =6802,952 \text { detik } \\
& =1,890 \text { jam } \\
& =\text { Bave }-2 . \text { slide slope } \mathrm{x} 1 / 2 \mathrm{H}_{\mathrm{ak}} \\
& =91,802-2 \times 1 \times 1 / 2 \times 15 \\
& =76,802 \mathrm{~m}
\end{aligned}
$$

tf

$\mathrm{Wb}=$ Bave -2 . slide slope $\mathrm{x} 1 / 2 \mathrm{H}_{\text {akhir }}$ keruntuhan

dimana:

$$
\begin{array}{ll}
\mathrm{B}_{\text {ave }} & =\text { Lebar rerata rekahan } \\
\mathrm{K}_{\mathrm{o}} & =\text { Konstanta }(1,3 \text { untuk keruntuhan overtopping dan 1,0 untuk piping }) \\
\mathrm{V}_{\mathrm{w}} & =\text { Volume tampungan air waduk } \\
\mathrm{W}_{\mathrm{b}} & =\text { Lebar rekahan bagian bawah } \\
\mathrm{h}_{\mathrm{b}} & =\text { Elevasi puncak bendungan }- \text { Elevasi dasar bendungan } \\
\mathrm{g} & =\text { Koefisien gravitasi }\left(9,81 \mathrm{~m} / \mathrm{s}^{2}\right) \\
\mathrm{tf} & =\text { Waktu mulai keruntuhan bendungan }
\end{array}
$$

Parameter slope rekahan menurut Froehlich (2008)

$1 \mathrm{H}: 1 \mathrm{~V}=$ Keruntuhan akibat overtopping

$0,7 \mathrm{H}: 1 \mathrm{~V}=$ Keruntuhan akibat piping 
b. Hasil Simulasi Keruntuhan

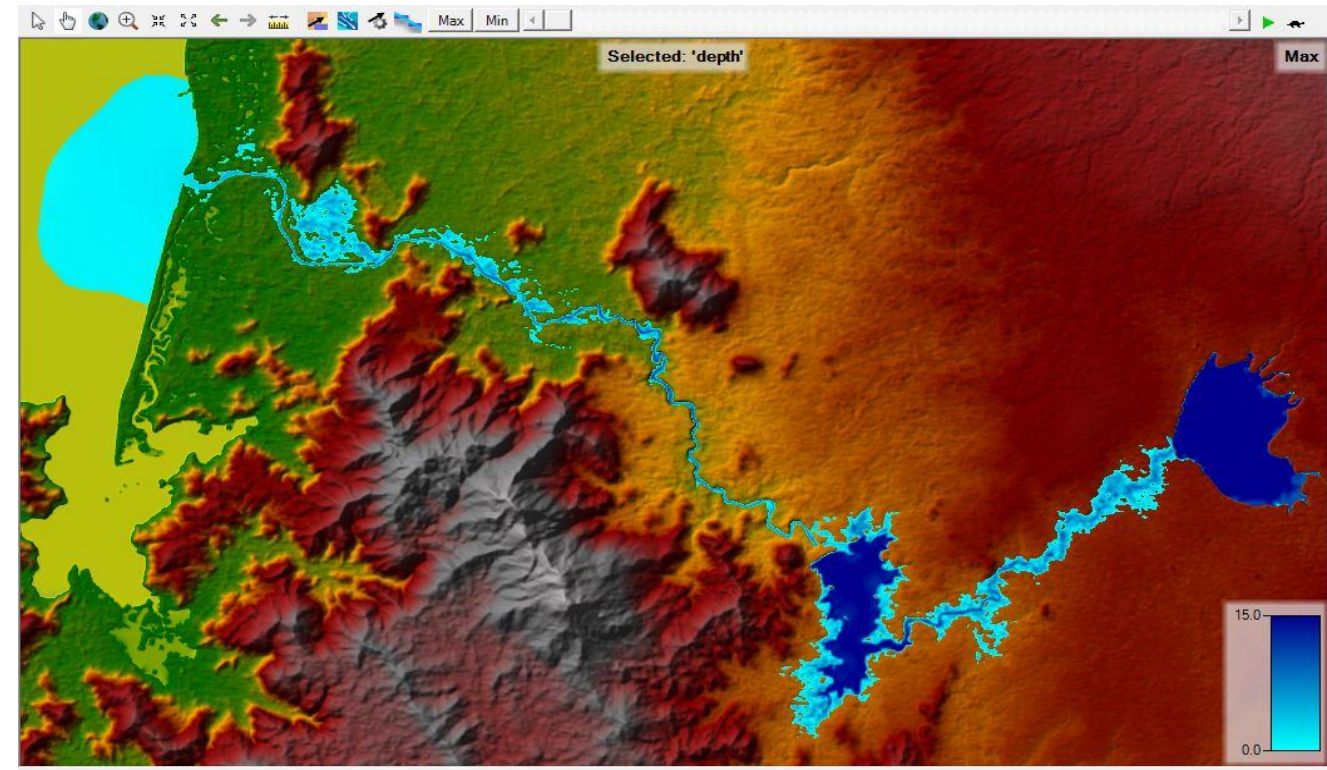

Gambar 8: Sebaran Genangan Banjir akibat Keruntuhan Bendungan Batujai

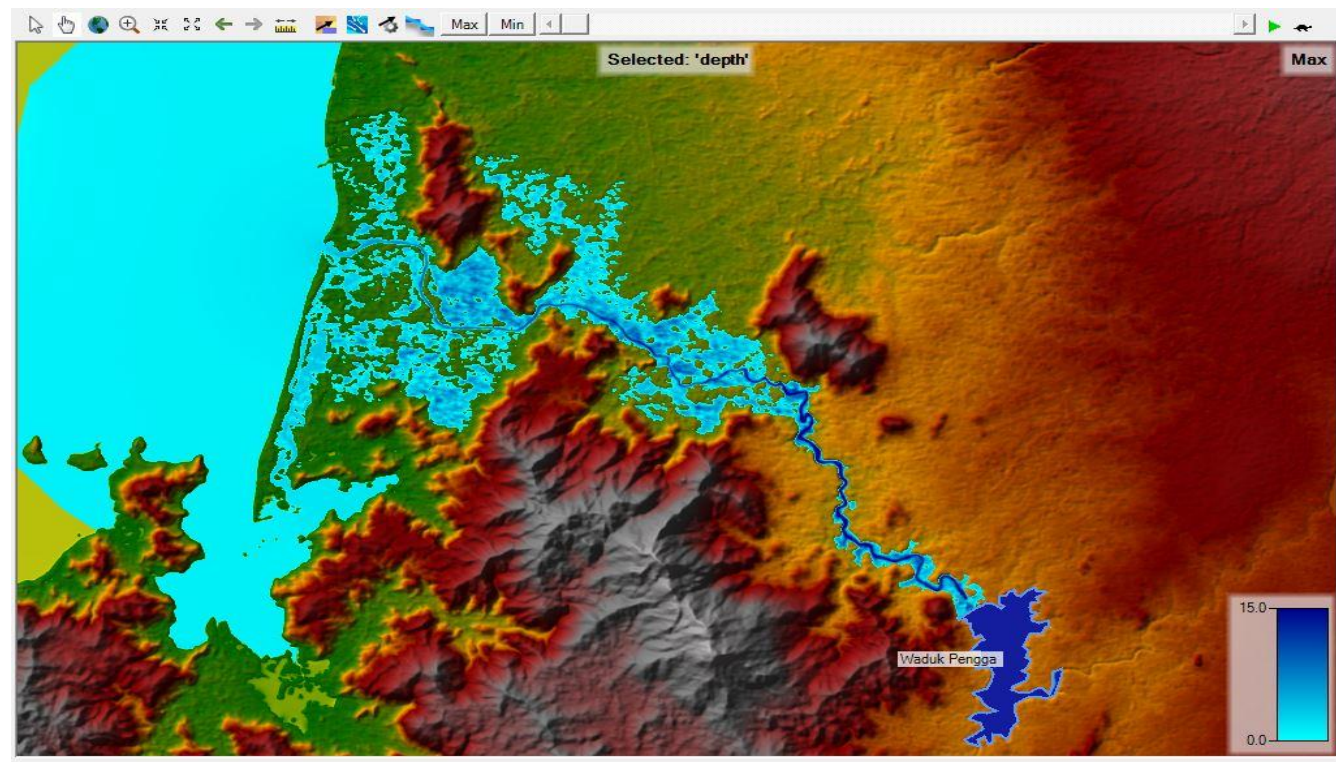

Gambar 9: Sebaran Genangan Banjir akibat Keruntuhan Bendungan Pengga

Tabel 6: Luas Genangan Banjir akibat Keruntuhan Bendungan Batujai

\begin{tabular}{clcccc}
\hline \multirow{2}{*}{ No } & \multirow{2}{*}{ Simulasi Keruntuhan } & \multicolumn{2}{c}{ Panjang } & \multicolumn{2}{c}{ Luas } \\
& & $\mathrm{m}$ & $\mathrm{km}$ & $\mathrm{m}^{2}$ & $\mathrm{~km}^{2}$ \\
\hline 1 & Overtopping & 242204,953 & 242,205 & 34126607,354 & 34,127 \\
2 & Piping MAB Atas & 85883,597 & 85,884 & 13123362,364 & 13,123 \\
3 & Piping MAB Tengah & 83469,979 & 83,470 & 12989791,070 & 12,990 \\
4 & Piping MAB Bawah & 83430,965 & 83,431 & 12986070,082 & 12,986 \\
5 & Piping MAN Atas & 77684,522 & 77,685 & 12217988,879 & 12,218 \\
6 & Piping MAN Tengah & 76484,277 & 76,484 & 12185364,867 & 12,185 \\
7 & Piping MAN Bawah & 76483,612 & 76,484 & 12185845,134 & 12,186 \\
\hline
\end{tabular}


Tabel 7: Luas Genangan Banjir akibat Keruntuhan Bendungan Pengga

\begin{tabular}{clcccc}
\hline \multirow{2}{*}{ No } & \multirow{2}{*}{ Simulasi Keruntuhan } & $\mathrm{m}$ & $\mathrm{km}$ & $\mathrm{m}^{2}$ & $\mathrm{~km}^{2}$ \\
\hline \hline 1 & Overtopping & 456059,630 & 456,060 & 107024742,680 & 107,025 \\
2 & Piping MAB Atas & 455500,736 & 455,501 & 106867179,814 & 106,867 \\
3 & Piping MAB Tengah & 453930,052 & 453,930 & 106717046,978 & 106,717 \\
4 & Piping MAB Bawah & 453686,168 & 453,686 & 106561635,084 & 106,562 \\
5 & Piping MAN Atas & 455820,443 & 455,820 & 106754830,000 & 106,755 \\
6 & Piping MAN Tengah & 453824,151 & 453,824 & 106581253,658 & 106,581 \\
7 & Piping MAN Bawah & 452430,695 & 452,431 & 106397886,054 & 106,398 \\
\hline
\end{tabular}

Tabel 8: Kedalaman Banjir akibat Keruntuhan Bendungan Batujai

\begin{tabular}{clccc}
\hline No & Simulasi Keruntuhan & $\begin{array}{c}\text { Depth Max } \\
\mathrm{m}\end{array}$ & $\begin{array}{c}\text { Mean Depth } \\
\mathrm{m}\end{array}$ & $\begin{array}{c}\text { Jarak dari Bendungan } \\
\mathrm{m}\end{array}$ \\
\hline \hline 1 & Overtopping & 19,656 & 9,397 & 12976,024 \\
2 & Piping MAB Atas & 12,985 & 8,054 & 4450,780 \\
3 & Piping MAB Tengah & 12,928 & 7,869 & 4451,875 \\
4 & Piping MAB Bawah & 12,925 & 7,864 & 4451,458 \\
5 & Piping MAN Atas & 12,772 & 7,026 & 12976,024 \\
6 & Piping MAN Tengah & 12,369 & 6,950 & 12975,123 \\
7 & Piping MAN Bawah & 12,368 & 6,950 & 12975,200 \\
\hline
\end{tabular}

Tabel 9: Kedalaman Banjir akibat Keruntuhan Bendungan Pengga

\begin{tabular}{clccc}
\hline \multirow{2}{*}{ No } & Simulasi Keruntuhan & $\begin{array}{c}\text { Depth Max } \\
\mathrm{m}\end{array}$ & $\begin{array}{c}\text { Mean Depth } \\
\mathrm{m}\end{array}$ & $\begin{array}{c}\text { Jarak dari Bendungan } \\
\mathrm{m}\end{array}$ \\
\hline 1 & Overtopping & 19,837 & 13,730 & 6725,383 \\
2 & Piping MAB Atas & 19,913 & 13,817 & 5846,841 \\
3 & Piping MAB Tengah & 19,970 & 13,848 & 5846,345 \\
4 & Piping MAB Bawah & 20,056 & 13,885 & 5846,789 \\
5 & Piping MAN Atas & 19,815 & 13,710 & 6725,383 \\
6 & Piping MAN Tengah & 19,805 & 13,696 & 6725,123 \\
7 & Piping MAN Bawah & 19,792 & 13,680 & 6725,456 \\
\hline
\end{tabular}

Dari gambar dan tabel diatas memberikan hasil yang sangat beragam, namun dapat disimpulkan dari luas banjir, kedalaman banjir, dan kecepatan banjir, bahwa keruntuhan kedua bendungan dengan kondisi terekstrim dihasilkan oleh sekenario overtopping, dengan perbedaan keruntuhan Bendungan Pengga mencapai laut sementara tidak dengan Bendungan Batujai. Hal ini disebabkan karena air dengan inflow QPMF dan parameter yang diisi, Bendungan Pengga masih dapat menampung air banjir dari Bendungan Batujai selama 3 jam setelah banjir masuk melalui sungai sebelum akhirnya ditampung oleh Waduk Pengga.

Hasil dari simulasi keruntuhan Bendungan Batujai dengan HEC-RAS 5.0.7 memperlihatkan bahwa terdapat 29 Desa yang terdampak dan hasil keruntuhan Bendungan Pengga menyebabkan 23 Desa yang terdampak. Jika kedua peta banjir ini digabungkan, maka akan menghasilkan 34 Desa yang terdampak oleh banjir akibat keruntuhan kedua bendungan. Rincian desa terdampak dapat dilihat pada Gambar 9. 


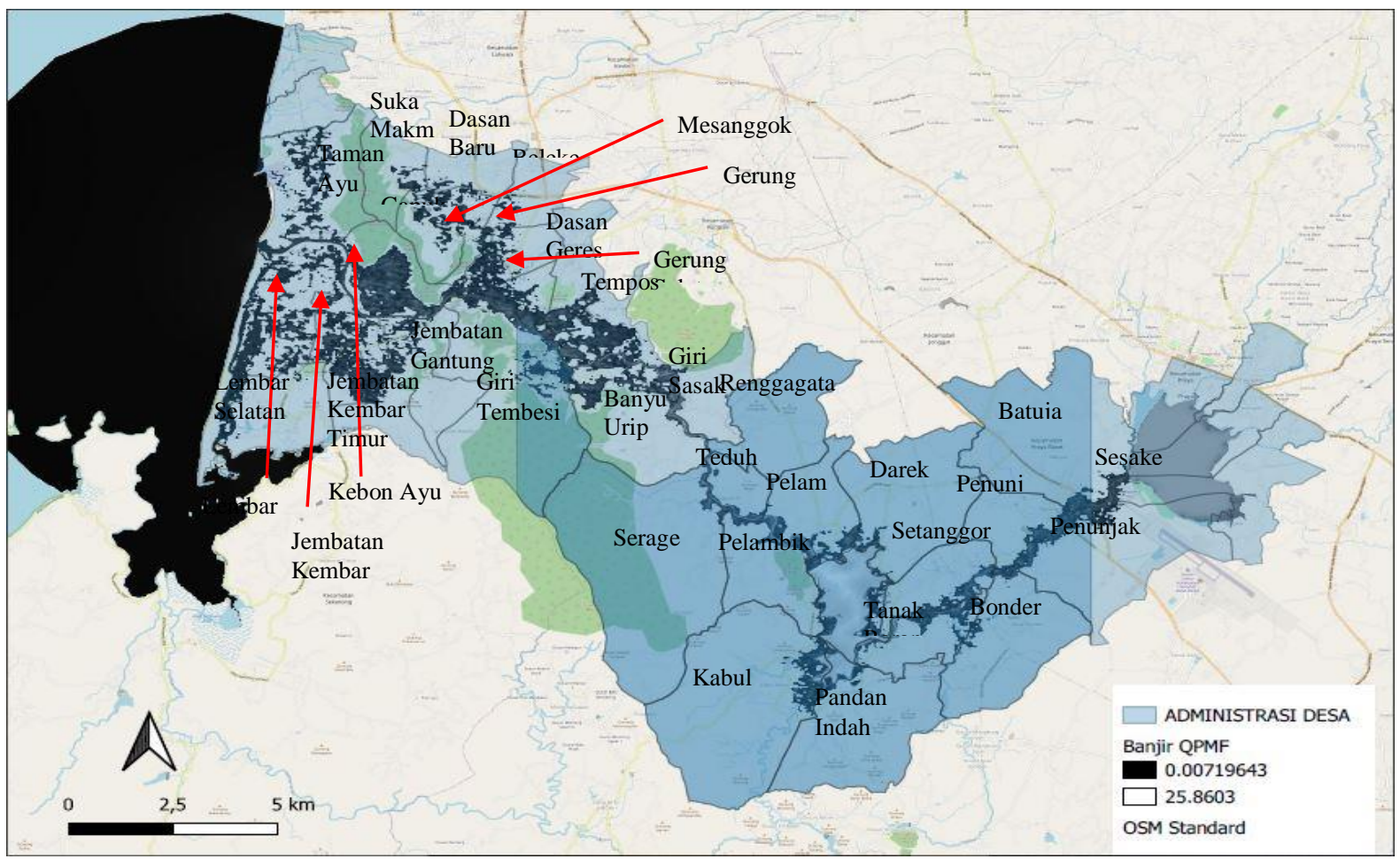

Gambar 10: Sebaran Banjir di 34 Desa terdampak akibat Keruntuhan Bendungan Batujai dan Pengga

\subsection{Klasifikasi Tingkat Bahaya}

Hasil dari analisa keruntuhan Bendungan Batujai dan Pengga yang telah dilakukan dengan bantuan aplikasi InaSAFE 5.0.1 menunjukkan bahwa dengan panjang banjir 36,94 Km dan luas total 141,152 $\mathrm{Km}^{2}$ terdapat 34 Desa yang tergenang banjir dan 29.100 jiwa yang harus diungsikan.

Sesuai dengan indeks tinggi banjir, jika kedalaman banjir diatas 3 meter dengan penduduk yang terdampak lebih dari 1000 jiwa [10], maka dapat disimpulkan bahwa keruntuhan kedua bendungan merupakan bahaya dengan klasifikasi tinggi.

\subsection{Analisa Kerugian}

Berdasarkan analisa kerugian yang telah dilakukan, kerugian akan ditanggung oleh pemerintah dan atau pengelola bendungan diperkirakan mencapai Rp. 2.845.409.886.907. Dengan luas banjir total akibat keruntuhan Bendungan Batujai dan Pengga 141,152 Km² atau 14115,2 Ha, maka dapat dikatakan bahwa kerusakan yang dialami oleh daerah terdampak yang tergenang banjir sekitar Rp.201.584.808,36/Ha. Hal tersebut sudah mencakup kerugian ekonomi, materil langsung dan tak langsung, dan kerugian fungsional.

\subsection{Desa Evakuasi}

Pada Peraturan Kepala BNBP No.7 Tahun 2008 dikatakan tempat evakuasi atau penampungan sementara adalah tempat tinggal sementara selama korban bencana mengungsi, baik berupa tempat penampungan massal maupun keluarga, atau individual [11]. Berdasarkan analisa yang telah dilakukan, terdapat 14 Desa terdekat yang dapat diakases sebagai Desa evakuasi untuk pengungsi yang terlanda banjir. 


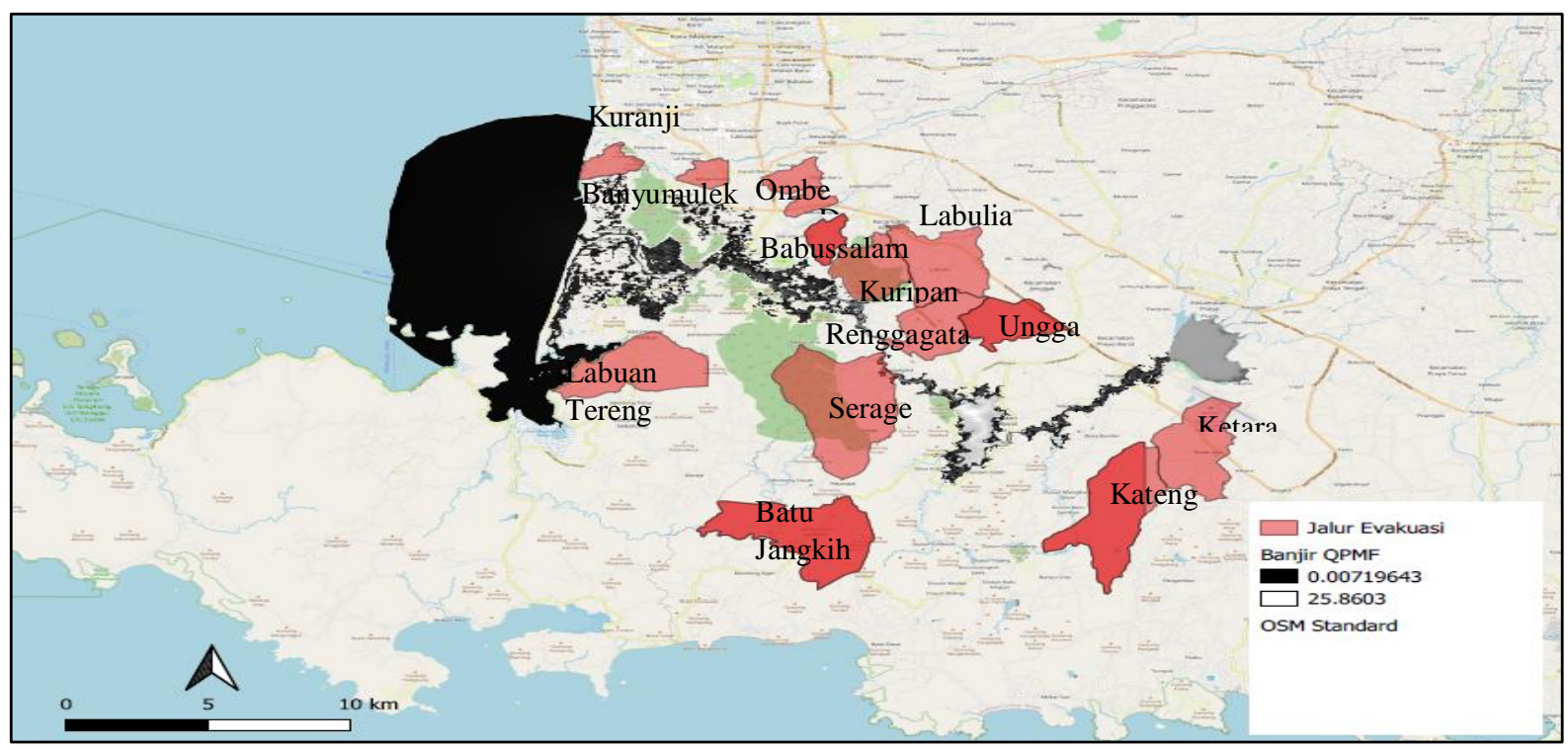

Gambar 11: Sebaran 14 Desa Evakuasi terdekat

\section{Kesimpulan}

Berdasarkan analisis yang telah pada Bendungan Batujai dan Bendungan Pengga, dapat disimpulkan bahwa kedua keruntuhan bendungan dihasilkan oleh kondisi terekstrim yaitu overtopping. Jika kedua peta keruntuhan digabungkan, maka akan menghasilkan 34 Desa yang rawan akan banjir, dengan 29.100 jiwa yang terdampak dan memiliki indeks ancaman dengan klasifikasi tingkat tinggi, dengan kerugian sebesar Rp. 2.845.409.886.907 atau Rp.201.584.808,36/Ha.

\section{Daftar Pustaka}

[1] Putri LA, Juwono PT. 2018. Analisa Keruntuhan Bendungan Ponre Ponre Di Kabupaten Bone Provinsi Sulawesi Selatan Dengan Menggunakan Program Zhong Xing HY21.

[2] Peraturan Menteri Pekerjaan Umum dan Perumahan Rakyat Republik Indonesia No.27/PRT/M/2015 tentang Bendungan. 2015. Jakarta

[3] Balai Wilayah Sungai Nusa Tenggara I. 2019. Katalog DAS Dodokan. Mataram: BWS NT I

[4] Soewarno. 1995. Hidrologi Aplikasi Metode Statistik untuk Analisa Data.. Bandung: Nova

[5] Soemarto, C.D. Hidrologi Teknik. 1987. Surabaya: Usaha Nasional

[6] SNI 2415. 2016. Tata Cara Perhitungan Debit Banjir Rencana. Jakarta: Badan Standarisasi Nasional

[7] Bambang Triatmodjo. 2008. Hidrologi Terapan. Yogyakarta

[8] Limantara, Lily M. 2010. Hidrologi Praktis. Bandung: Lubuk Agung

[9] US Army Corps of Engineers Hydrolic Engineering Center. 2014. User Guide Using HEC-RAS for Dam Break Studies. CA

[10] Peraturan Kepala Badan Nasional Penanggulangan Bencana No. 02 Tahun 2012 tentang Pedoman Umum Pengkajian Risiko Bencana. 2012. Jakarta

[11] Peraturan Kepala Badan Nasional Penanggulangan Bencana No. 07 Tahun 2008 tentang Pedoman Tata Cara Pemberian Bantuan Pemenuhan Kebutuhan Dasar. 2008. Jakarta 